\title{
Affricates and affricated consonants in Aromanian spontaneous speech
}

Anastasia Kharlamova

Department of General Linguistics, Saint Petersburg State University, Russia

https://oi.org/10.36505/ExLing-2017/08/0015/000317

\begin{abstract}
This paper deals with affricates and affricated consonants in Aromanian, an Eastern Romance language and member of the Balkan Sprachbund. The materials for the study were obtained in Greece, FYRM, and Albania. The current goal is to analyze the processes that concern affricates in Aromanian spontaneous speech, the main of which are the loss of stop phase in dental affricates and the affrication of dental stops before front-row vowels. Furthermore, we hope to determine the reflection of the speakers' bilingualism in the phonetics of their speech.
\end{abstract}

Keywords: phonetics, affricates, dental consonants, spontaneous speech, Balkan languages

\section{Introduction}

Aromanian spontaneous speech has practically never been the subject of a separate study before, the only known exceptions being our own research from previous years that have dealt with the topic (Харламова 2015; Kharlamova 2016). Spontaneous speech studies have mostly been conducted using the data of more widespread languages such as English, German, Russian, or French.

This paper is dedicated to affricates and affricated consonants in the spontaneous speech of Aromanians in Turia (Greece), Resen (FYRM), and Elbasan (Albania). The Turia materials were gathered in 2002 by an expedition supported by Kleiner Balkansprachatlas project (see Bara et al. 2005 for detailed description); the data from Resen and Elbasan was obtained during our own expeditions in 2015 and 2016 respectively.

The goal at our current stage of research is to fully analyze the phonetic processes that affricates and affricated consonants undergo in Aromanian spontaneous speech.

\section{Affricates in Aromanian}

Phonology of Aromanian is a very underdeveloped field of study, with practically all research done in that area concerning only separate dialects, many of which are vastly different from each other in matters such as pronunciation of diphthongs, central vowels etc. It is usually acknowledged that there are four affricates in Aromanian: [ts], [dz], [t $]$, and [dz] (Нарумов

ExLing 2017: Proceedings of 8th Tutorial and Research Workshop on Experimental Linguistics, 19-22 June, Heraklion, Crete, Greece 
2001). However, our analysis of spontaneous speech also provided occurrences of [t's'], [d'z'], [cç], and [ji] (the latter two are most probably a result of Albanian influence since they occur across Albanian dialects).

The two main processes that involve the affricate inventory in Aromanian spontaneous speech are the loss of stop in dental affricates and the affrication of dental stops before front-row vowels.

Having transcribed our texts using Sound Forge and Speech Analyzer, we now seek to analyse these processes, mainly the factors that cause them.

\section{Phonetic factors}

The loss of stop in affricates is quite widespread typologically (Kümmel 2007: 376-409), to the point that it is often believed to be a regular stage of affricate evolution. In our materials we have already seen, during our previous stages of research, that the stop in dental affricates is usually lost in short and frequently used words such as ți 'what'. Now our purpose is to find out how it depends on phonetic surroundings and on the lexeme's origin.

Currently we can say that affricates in Romance words experience the loss of stop more often than affricates in borrowings. The main reason for it, as we believe, is the fact that most of the frequent words containing dental affricates are originally Romance. As for the phonetic surroundings, we should say that an affricate is more likely to lose its stop: a) before a central vowel (such as d̦āsi 'said' pronounced as [zəs']) b) after [n] (such as munți 'mountains' pronounced as [muns]) c) in the end of the word (multiple examples of verb forms with an orthographic $t$ in the end were pronounced in our data with [s]).

As for the affrication of [t], it is limited and occurs only before front-row vowels ([i], [e], [ea], [y]). The evidence from our data suggests that a preceding hissing consonant might also serve as a factor of the affrication (such as [J] in aromanešti 'Aromanian', pronounced as [aruməne $\int t$ 's'i]).

We are going to further analyze the phonetic conditions of the loss of stop and affrication, taking into consideration suprasegmental factors such as word stress and the consonant's position in relation to it.

\section{Extralinguistic factors}

In addition to the phonetic factors listed above, we would also like to mention some extralinguistic factors that, as we believe, may influence the pronunciation of affricates in different lexemes.

First, rare affricates [t $\left.\int\right]$ and [dz] mostly occur in loanwords, many of which have Turkic origin (or get borrowed from Turkic languages via Albanian). Numerous Turkic borrowings (for example, xhami 'mosque'), first, are pronounced in practically the same way in all Balkan languages, second, particularly in Aromanian, tend to belong to a limited semantic field 
(Islamic terminology, some terms of handicraft etc.). Therefore, these words don't belong to the active vocabulary of most of our informants (Aromanians are Orthodox Christians and therefore may avoid Turkic words for religious reasons as well), and they are not involved in phonetic processes of spontaneous speech as they are usually pronounced "carefully", for example, in response to a linguist's phonetic questionnaire.

Second, we should also notice the status of the Aromanian language. It is officially a national minority language only in FYRM; however, cultural activity of Aromanians in Albania has also risen in recent years. In Greece, many Aromanians identify themselves as the Greeks and their language as Greek (more information on the problem of the Aromanians' national identity can be found in Nedelkov 2009).

Our informants in Resen, FYRM, are the only family in their town to use the language, and even they hardly use it spontaneously and mostly preserve it as heritage. From our Albanian informants only one (an elderly man) speaks Aromanian fluently; the next generation (his two nieces) only remembers some words. Only in Turia could truly bilingual Aromanians be found, speaking both Aromanian and Greek from their childhood (Bara et al. 2005).

Therefore, a big part of our data consists of spontaneously read texts rather than "truly spontaneous" speech. Although it has been noted that spontaneous reading has the necessary level of spontaneity to be included in spontaneous speech studies (Богданова-Бегларян и др. 2013: 150), with a language like Aromanian which is not often in common use we should remember that phonetics of spontaneous reading is less likely to have active reduction and sound change processes that are characteristic for the "truly spontaneous speech".

There is also the fact that Aromanian texts are usually written in a "literary" form ${ }^{1}$ which is intended to be as purely Aromanian as possible, while spoken Aromanian is the speech of bilinguals and always experiences the results of close language contact. The problem of the Aromanians' bilingualism is the subject of our future steps of research, as well as the question of whether a bilingual possesses a single phonetic system or a separate one for each language.

\section{Notes}

1. There is no officially acknowledge literary or standard Aromanian.

\section{Acknowledgements}

This paper was completed as part of a research project supported by RSF 1418-01405 grant. I would like to thank my informants, the Andonovski family 
from Resen and the Kristo family from Elbasan, whose friendliness, hospitality and cooperation made this study possible, as well as my colleague A.L. Makarova who helped me with finding informants in Resen and my tutor Prof. A.N. Sobolev who provided me with Aromanian audio materials from Turia.

\section{References}

Bara M., Kahl T., Sobolev A.N., 2005. Die südaromunische Mundart von Turia (Pindos). München, Biblion Verlag.

Kharlamova A.V., 2016. Affricates in the spontaneous speech of Aromanians in Turia. In: ExLing 2016: Proceedings of 7th Tutorial and Research Workshop on Experimental Linguistics, 67-70. University of Athens.

Kümmel M. 2007. Konsonantenwandel: Bausteine zu einer Typologie des Lautwandels und ihre Konsequenzen für die vergleichende Rekonstruktion. Wiesbaden, Reichert Verlag.

Nedelkov J.L. The Ethnic Code of the Vlachs at the Balkans // EthnoAnthropoZoom. №6 / Ed. A. Svetieva. - Skopje: St. Cyril and Methodius University, 2009.

Богданова-Бегларян Н.В., Бродт И.С., Куканова В.В., Павлова О.В., Сапунова Е.М., Суббота И.А., Филиппова Н.С., Хан Н.А., Чуйко В.М. и др., 2013. Звуковой корпус как материал для анализа русской речи. Часть 1. Чтение. Пересказ. Описание. Санкт-Петербург, Филологический факультет СПбГУ.

Нарумов Б.П., 2001. Арумыский язык/диалект. In.: Языки мира. Романские языки, 636-656. Москва, Academia.

Харламова А.В., 2015. Опыт фонети.ческого анализа арумынской спонтанной речи (на материале южноарумынского говора села Турья). In: XVIII Международная конференция студентов-филологов. Тезисы докладов, 214 215. Санкт-Петербург, Филологический факультет СПбГУ. 